chenistry explains more or less suceessfully the proceses juvolved in digestion. But the exact mamer in which the intestinal mucous-memb!ane cell takes up nany of the products of digestion from the intestine and passes them into the circulation is not well determinerl. ${ }^{11,12}$ The mucoms membrane seems to be a most wonderfully appointed living chemical laboratory. Some of its celss are capable of producing ferments which subdivide and chemically prepure food-substances so that other ecels may absorl, them, reunite elements and form new chemical compounds which pass on into the capillaries and lymphaties. 'The small intestine also produces a ferment which destroys bacteria, as shown by Fleiner. ${ }^{13}$

In the ileocecal regrion a most varied bacterial flora eomplicates still further these physiologic problems. 'The activity of these bacteria on the various food-elements, on the digestive ferments, on the cells of the murous membmanes and on the hacteria themselves is far from being fully umderstoon. In the cecum certain varieties destroy the digestive ferments, thereloy ending digestion. while other's cause fermentation and putrefaction of umaborbed products of "arloyedrate and proteid foods, respectively. ${ }^{14}$ Still other bacteria seem to have a mission of regulating the number and life-history of the former varieties. 'The Bacillus coli commmnis group probubly belongs to this class. After the fluids have been absorbed from the bowel-contents in the colon and the fecal masses are hardened, the bacteria are found to be mostly dearl. Thend bacteria make up one-thirel of the volume of had leces. ${ }^{15}$

'The interolationship between the varions bacterial gromes, and between them and the food-products and the physiologric elements of the intestine must be at a certin equilibrium. 'This interdependence between the elements involved may be quite individual. The life-listory of the majority of these bacteria is short, lasting but a few hours. Jefore meals the small intestine is nearly if not quite sterile and in the large bowel the burteria are lying off rapidly, owing to autotoxic activity. Alter a full meal the bacteria again proliferate with astonishing rapility throughout the intestinal truct. When generations follow one another in such rapidity, evolutionary chenges may be possible within the spaee of a lew months or yenrs. It is rensomalble, therefore, to think that ench individual may have his own peculiarly cleveloper type of a criven bacterium (Bacillus coli commanis, for justance), which in the course of time and development has berome necessary in this particular intestine to balance amd check up the activity of the other bacteria and ferments. Acoording to Kendall, the greatest interdepemolenes among feenl buctroba exists between the formentative and the putrefactive typesthe former decomposing the arbohydrates and the latter the proteids. $\Lambda$ marked disturbance of their relative activities will cause excessive gas formation and perhmps diarrhea, the symptoms of so-called "intestimnl fermentation."

An individual who ents habitually a varied diet, who seceretes normal gastric, pancreatic and intestinal juices, who las a pronerly functionating neuromuscular nponmatus for peristalsis, and who has an evenly balaned colonic bacterial flora-such an individual enjoys intestimal comfort. Whenever any one of these lactors is arficient or excessive in its activity, the intestinal balanee

11. H[ownt] : Text-Hook of l'hyslology.

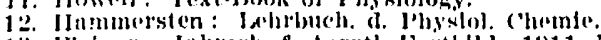

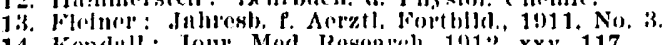

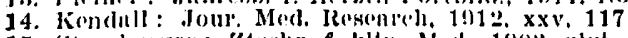

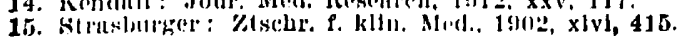

is upset and the indivilual suffers discomfort and symptous in proportion to the lerangement. ${ }^{13}$

We are apt to think of the function of peristalwis as being limited to the propulsion of intestinal contents. It is easily conceived, lowever, that the sucessive contractions and relaxitions of the intestines also eane alternately an ischemia and a hyperemia of the jntestinal wall. 'These eirculatory dhanges aid absorption from the mucosa and cause a more mpid ilisseminntion of absorbed sulostances into blood-vessels and lymphatices. ${ }^{10}$

From this fact we should deduce a lesson in pathologyIf pathologic products exist in or nbout the intestine, incensed peristalsis may cumse mo incrensed toxomia. Incrasen peristalsis also mons a mechanical spreading of infection on the peritonemm and a delay in the formation of protective adhesions.

In acute inflammations within the abdomen. Nature's first eflort is to subrlue preristalsis about the region of infection. ${ }^{17}$ Hor next ellort is lo confine the inferetion within the smallest possible nrea by means of peritoneat allhesions.

Ilere we find another lesson. This is one in thorapy and reals plainly as follows: Tn necute intra-abdominal infections do nothing to incense peristalsis. ${ }^{1 \mathrm{H}}$

When we desire to evacunte the bowel rapidly it is a time-worn custom to give a saline purgative. In the smatl intestine " ancentrated saline solution camsos a profuse transudation of fluids into the intestine. 'The colon loses its absorptive power from the presenee of the salt and its contents are expelled in liquid form. Peristakis is increased most markedly in the larere bowel. 'This transudative effect on the mucosa of the small jntestine interferes with the formation of ferments. 'The zrmogen-colying cells become clepleted of the necessary fiud. But, the errentest factor in this dernengement of intestinal balance is, perhajes. the destruction of the bartericidal principle. the cecem mabsorbed and in a state of but partial dierestion. 'The fermentative and putrefuctive bacteria find the best possible comditions for their existence and proliferation. Thant lhey improve thoir oplontunity is showr not only by the fact that the diarrheal stool is teming with living bacteria, but also by the gas distention of the colon experienced by most indivirlumb as an alter-effect of a dose of salts.

It may socm almost a sacrilese, lut we cannot except even calomel fromi our criticism of salines in genernl. calomel was formerly thought to be both a biliary stimulant and an efficient intestimal antiseptic. Sohiitz las shown it to be neither, but ruite the contrary. Aceoreting to this and other' nuthorities, ${ }^{1:}, 20$. the netion ol calomel on the intestinal mueose is harmful and in favor of bacterial growth.

When a cathartic is neresenry, oil is probubly the least hamful to the intestimal mucesa. Oil does not destroy the disinferting property of the suceres enterieus and it forms a grool lubriant for the arolon. ()il surrounds and impregnates the food particles. This retards bacterint artivity, and therely reduees gas formation.

$\Lambda$ high rectal cnema reaches and flushes the whole length of the colon. 'This ean be proved to nny donbter by giving it to a patient while the abdomen is opencel so thit the large bowel can be secn. $\Lambda$ sult solution, stronger than normal saline, or practically any other

16. Mull : Jolins IIopklns IJokp. lkep., 1890, No. 1.

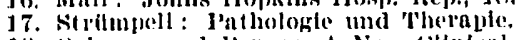

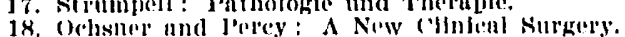

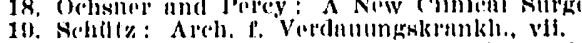

20. Nickels: IReference Handbook Medicul Sclence. 
irritant in an enema reaching berond the splenic flexure will often cause immerliate evacuation. ('umnom observed increased peristalsis even in the ileum as a lesult of the stimulus from an enema of sompsuds." should the cnema fail, an irrigation of the colon is possible.

An internal secretion which stimulates peristalsis has been obtained from the wastric mucesa and from the spleen. 'J'he experinents of Dohrn, Marxer' and /malzer $^{21}{ }_{22}$ showed that this is a comstant hormone in animal organisms regulating the function of peristalsis. 'Theratpeutically it has heen used to some extent, but will need further experimentation and use before dofinite indications for its employment an be established. When this is done it pronises to become a plysiologrienlly idenl intestinal evacuant.

After this briet review over several facts concerned in the functions of the bowels, and over the action of some of the common cathartics, let us see what clinical observation teaches in regard to the use and nom-use of cathartics, especially in certain surgical combitions.

I have searched my clinical recorrls and experiences with respect to this question and found that the patients with acute appendicitis whom I have seen die from locil extension of the disease, or from general sepsis, either with or without surgical intervention, had without an exception recoived and retained some active cathartice at the beginning of the disease. The patients with discases of similar nature who have barely escaped denth, but who have developed the worst postoperative compliations, advancing peritonitis, bowel paresis, distention, fe(al] fistulas and miserere, had nemly all been given a dose of salts as a passport to prolonged suflering, telious and expensive stay in the hospital, and finally months or years of reduced vitality and uscfulness. (On the other hand, the cases of acute intra-abdominal inflammation which had an equally stormy onset and which apparently promised fully as grave complications as those alrealy mentioned, but into which the element of purgation hail not entered - in these cuses the putients had in comparison a surprisingly easy and quisk recovery.

Descriptions in cletail of jllustrutive cases as well as a classification of all such patients would be of interest, but time-limit forbids. I feel, however, that my experiience along this line has been grent enough to warrant the greatest possible attention to the facts stated. The country practitioner has here a grave responsibility. Beyond his duty to each individual patient. he should he a missionary among the uninformet. It has become a custom whenever a patient with neute appendicitis or other acute inflammation about the movable viscern is brought to me, to inquile at once: "Have you taken a physic?" If this question is mswered in the affirmative. the next question is whether the stomnch resented the insult with free emesis, or whether the enthartic were retained to perform its malicious work. This knowled re is of importance in prognosis. Sat experience has bern my teacher.

About two years ago my attention was drawn to the fact that most paticnts who were suljected to abdominal operations immerliately on their admittunce to the hnspital, on account of strangulated hernia, acute appendicitis or other abdominal emergeney, recovered with but slight discomfort from gas distention. During the same time other patients who had been deliberately prepared for operation and who had received fully as careful and 21. Dohrn, Marxel and Zuelzer: Berl. klln. Wchnschur., 1008,
22. Zuelzer.

1910, vi. dolicate handling of peritoneum and viseera as the former fatients, sulferenl relatively much more from meteorisin and pain and had a more serious time in getting the howels opened after the operntion, than had the emergency cases. The relation between operative trauma and jostoperative gas puin was decidedly in favor of the "umprepared cales."

A roser study about these cilemustances led me to believe that this diflerence in results must have its canse in some ste]) in the preparation of the patient before the operation. 'That the operative technice was a radical factor coubl not he assumed, for several reasons. In a stlangulatel hernin, for instance. the intestine would be handled and rubbed with fingers, gaume and instrumicnts, and perhaps resected, and yot the intestinal contents would not be muterialy hindered in thoir transit. ('omparatively litile gas would be formed in the bowel. ln immediatc operations for neute appendicitis, the peritomemom would he opened fleely, ganze pads would be laid over omentum and numesous loops of intestine and hold firmly agrainst the peritonem by intra-ablominal pressure. Many such pationts recovered with a surprisingly sminl amoint of meteorism. On the other hand, an interval appendectomy, a gall-bladder incision, a pelvic operation would at times be followed by two or three lays of distention and distress before the bowel conld be induced to functionate properly. And this would sometimes happen after the most painstuking preparation of the pratient, including a libernl use of cathartics a day or two before the operation with the crroneous iden that this would remove all gas-producing materials.

It was evident that the grentest difference in the prepnration of the two classes of patients lay in the nonadministration of carthortics in the emergency cases. I concluded therefore to leave out, by way of experiment, this feature of the preliminaries in ordinary laparotomies. 'This was done tentatively at first, but as experienee made me boleler and more confident I discontinued all use of purgatives before operations, exeept in rare instances and for specinl rensons. Instend of the classical dose of calomel and salts, two or three high enemas were given to flush out the colon.

I lave followed this practice now for over a year to the great satisfaction of pationts, murses and surgeons. lt inchudes operations on the stomach, gall-bladder and ducts, intestine, uterus, tubes and ovaries.

A bowel that has not been vitinted by a saline scouring is in condition, physiologically and bacteriologically, to prevent the excess formation of gases, and to expel those that do form. It is the gins distention which eauses the bulli of the postoperntive distress. 'This compliention being reduced to a minimum. fecil eontents are taken care of by normal peristalsis or by enemas if required.

The following are the most important conclusions which I lave reached after a study of this subject:

'The food normally passes rupidly from the stomach and through the small intestine. The small intestine is practically empty six hours after an average meal. In the cecum and colon the bowel-contents remain for from twenty-four to forty-cight hours.

'The maintenance of a certain equilibrium between the physiologic and bacterial processes in the intestine is necessary for normal bowel function.

Saline cathartics disturb this poise to a marked degree, making their use a matter of grave consideration.

At'ter the intestinal mucosa has been depleted and exhausted by any powerful cathartic, it takes some time 
to recover its enerery. During this time bacteria flourish unmolesterl by intestinal ferments.

Intestinal antisepsis is at best of unknown and doubtful eflicacy; a comparative asepsis is practical.

An artificial evacuation of the large bowel, satisfactory for most surgical and many other purposes, does not require the ingestion of any drug acting on the small intestine. High rectal injections are eflicient and cause less damage and discomfort.

$\Lambda$ cathartic given in the beginning of an acute intraabrominal infection is a rangerous practice and (onntraly to modern scientific knowledge and experience. Numberless gravestones mark the dispegard of this principle.

Tatients who are prepared for laparotomies by a restricted diet and rectal injections have a much more pleasant postoperative recovery than have the patients who lave been purenel.

\section{INTRA-ABDOMINAT, PRRSSURE}

I'S IMPOR'TANCE IN MAIN'TAINING S'PA'TC GQUILIBRIJAT AND THE NECLSSITY OF CONGORMING 'TO I'TS

LAWS IN TIE RESTORATION OF ORGANS TO THEIR NORMAL POSI'LIONS*

J. RIIDISIS (i()FFli, M.l).

I'rofessor of Aynecology at the New Yolk I'olyelinfe; Attending Surgeon to the Woman's Ilospltal: Attending Gynecologist to the Jolyellnle IJospltal; Consulting Giynccologist, Now Yolk ('ity Hospltal. Mount Vornon Ilosp!tul, St. Josiph's llos[iltal, Yonkers, and the Lawence Ilospltal, Bronxville

NEW YOIK

As the Roman gladiators in the days of old entered the arena to meet each other in dendly combat or to be torn to pieces by the fierce Numidinn lions, it was their custom to greet their andience with the expression Morituri salutamus! "W( who are about to die solute you!" Conscious of tha wide divergence of opinion on this subject of intra-ablominal pressure and knowing the powers and skill of the many gladiatols who enter this arena, to whom the Numidian lion is but a toy, I can only exclaim in the langunge of the ancients, "I who am about to die salute you." Jespite this depression of the hour I am buoyed up by the thought that out of the contest there may perhaps come some slight illumination on the subject or at least some inspiration for further investigation.

The universal application of abolominal section which lans come jnto vogue cluring the penst quarter entury for the relief of positive patholorie conclitions in the abdominal cavity las brought to light a startling frequency of ptosis, sometimes of one oring, sometimes of another, and occasiomally of all. Many arrd various surgical procerlures have been instituted for relief of these conditions hut with varying and uncertain suceess. Failure to ohtain satisfactory lesults las led cortain investigators to inquire into the causes of ptosis. And these wise men tell us that ptosis is rue to "abrlominal static conditions," that these conditions ne produced by "aberrant intra-ablominal pressure," which, in turn, is producerl by "faulty postures :" that "faulty postures" of the borly come from "lack of physical vigor and vitality," "that ptosis interferes with digestion and assimilation" and hence the lack of vitality. And so we gro around in this vicious circle, like a dog chasing his own tail.

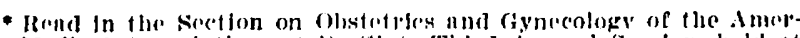

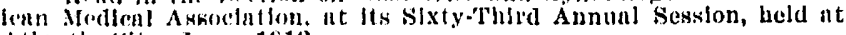
Atlantle tity, June, 1s!?
We can understand faulty postures; lack of vitality is comprehensible; ptosis we recognize when we see it; static comditions are explicalle, but the one link in the elanin that eludes us is intra-abdominal pressure. What is intra-abilominal pressure? Breathe sol'tly now, for we are on sacred ground. Intra-abdominal pressure is a great mystery.

At the meeting of the British Medical Association, Sheffield, Fingland, in 1909, I land the honor of being invited, as the American representative, to open the diseussion on displacements of the uterus and operative procedures for their relief. In these remarks I presented my conviction regarding ihe importance of lignments in maintaining the normal position of the nterus. Tn the general discussion which followed I was inlopmed by one of my British confrères that this matter hal all been settled in previous discussions on this subject; that lignments had nothine to do with the case; that ablominal and pelvic organs, as was well known, were held in place by intra-ablominal pressure and the floor of the pelvis; that the liver, which hat many square inches of space on the lower surface, was lifted up by an intra-abdominal pressure many times its weight.

It has interested me to discover what was being taught the present generation of medical students in regard to this matter, ly putting to the applicants who apply for positions as interns in the various hospitals with which T am connected the question: "How are the kidneys and the liver kept in place?" 'The common reply is, "l'he jigments may lonve something to do with it but the (hief support is negative pressure." When I inquire, "What is negative pressure?" the universal response is, "I don't know what it menns, but that is what I was taught."

Tet us revert again to the question, What is abdominal pressure? Intra-abdominal pressure may be defined ns pressure within the ablomen due to extermal ntmospheric pressure, to gravity, to muscular contraction of its walls and to intravisceral pressure. The first two, atmospheric pressure and gravity, are constant; the latter two, i. e., muscular contraction and intravisceral pressure, are variable and therefore constantly morlifying the intensity of the pressure. The intensity of intra-nblominal pressure at any time and in any place is the resultant of all these fores working together at the specified place and specified instant of time. Musculas contraction has reference not only to the abdominal wals, but also to the dinphragm, which forms the npper wall of the abtomen and modifies intra-nbilominal pressure witl every breatl. By intruvisceral pressure is meant the pressure produced by a full stomach in filling the aldominal cavity and thereby increasing the pressure. 'The stomach contents maty be solid, liquid or gus. This apmlies equally to the intestines. To a minor degree a full gall-bladiler or an enlared liver may increase intraabclominal pressure, and likewise any pathologie tmmor.

We all recognize that the specific gravity of the organs and other contents of the nlulomen do not vary much from that of fluids, and consequently, intra-ablominal pressure corresponds rosely but not nibsolutely to hyclostatic laws. If we press the abdomiual wall with the hand, the pressure is commumiented in all directions till it mects with organs or tissues that are of greater density. These comnot transmit the foree with equal facility and consequently they reflect what they cannot readily transmit, but finally are pushed before it till the force has been equally distributed and exuilibrimu has been attained. This moving force would be felt least by the 